\title{
A NEW GEOLOGICAL MODEL BASED ON A SEISMIC-STRATIGRAPHIC ANALYSIS OF THE EASTERN INHAMBÚ OIL FIELD, ONSHORE ESPÍRITO SANTO BASIN, BRAZIL
}

\author{
Igor de A. Neves, Wagner M. Lupinacci and Cleverson G. Silva
}

\begin{abstract}
The Espírito Santo onshore basin is an important hydrocarbon province on the eastern Brazilian continental margin that accounts for almost $9 \%$ of Brazil's onshore oil production. This study aims to understand the stratigraphy and geologic evolution of the eastern Inhambú onshore oil field from the post-rift section (Cricaré Formation, Mucuri Member) to the drift section (Rio Doce Formation). We interpret the main stratigraphic surfaces and seismic facies from the basement to the upper pre-Eocene unconformity to build a chronostratigraphic chart and identify the main transgressive and regressive events. Lithological and geophysical logs from new wells allowed the identification of six $3^{\text {rd }}$-order cycles, including four regressive and two transgressive events. Based on these results, a new conceptual geological model for the eastern Inhambú Oil Field is proposed.
\end{abstract}

Keywords: chronostratigraphic chart, seismic facies, Fazenda Cedro Canyon, Espírito Santo Basin.

RESUMO. A bacia terrestre do Espírito Santo é uma importante província produtora de hidrocarbonetos na margem leste do Brasil, respondendo por quase $9 \%$ da produção brasileira de petróleo em terra. 0 presente trabalho teve como objetivo entender a estratigrafia e a história evolutiva, desde a seção pós-rifte (Formação Cricaré, Membro Mucuri) até a seção drifte (Formação Rio Doce), de uma área a leste ao Campo de Inhambú e assim propor um novo modelo geológico para a área. Neste estudo, foram interpretadas as principais superfícies estratigráficas e identificadas as principais sismofácies desde 0 embasamento até a discordância do pré-Eoceno Superior, criando-se uma carta cronoestratigráfica de eventos. A interpretação de dados litológicos e geofísicos de poços permitiu o reconhecimento de seis ciclos de $3^{a}$ ordem, onde foi possível identificar quatro eventos com caráter regressivo, e dois de caráter transgressivo. Como resultado final foi criado um novo modelo geológico conceitual para a área leste do campo petrolífero de Inhambú.

Palavras-chave: carta cronoestratigráfica de eventos, sismofácies, Cânion de Fazenda Cedro, Bacia do Espírito Santo.

Universidade Federal Fluminense, Department of Geology and Geophysics, Niterói (GIECAR/UFF), Rio de Janeiro, Brazil - E-mails: igorgeol@gmail.com, wagnerlupinacci@id.uff.br, cguizan@id.uff.br 


\section{INTRODUCTION}

Hydrocarbon exploration in the onshore portion of the Espírito Santo Basin began in the 1950s with the drilling of the first stratigraphic well (2-CB-1-ES). However, the first commercial oil well was drilled almost two decades later in 1969 and resulted in the discovery of the São Mateus field. With continuous exploration in the 1970s, the Fazenda Cedro (1972) and Lagoa Parda (1979) fields were also discovered.

In January 2018, the production from the basin was 35,051 barrels per day (bbl/d). The onshore part of the Espírito Santo Basin contains approximately 55.7 million barrels of total reserves and 23.9 million barrels of proven reserves. Currently, the most important fields are the Fazenda Cedro (25.46\%) and Fazenda Alegre (25.45\%) fields, which account for nearly $50 \%$ of the total onshore production (Figs. 1 and 2).

The initial studies identified the sandstones of the Urucutuca Formation as the main reservoir rocks in the area. The petroleum accumulations are located in stratigraphic traps that are similar to the Fazenda Cedro and Fazenda Alegre fields. The main reservoir of the São Mateus Platform is the Mucuri Member of the Mariricu Formation, which consists of Neo-Aptian fluvial-deltaic sandstones that were deposited during a marine transgression that culminated with the deposition of the evaporites of the Itaúnas Member (França et al., 2007) (Fig. 3).

New wells drilled in the area (see Fig. 3 for locations) showed the absence of the Urucutuca Formation reservoirs at these locations (Neves et al., 2017). Because these were considered to be the main reservoirs in this part of the basin, in this study, we re-interpreted seismic and well data from the Inhambú oil field to define the main seismic units and stratigraphic surfaces with the intention of constructing a geological model that describes the distribution of the Inhambú Field reservoirs. We followed the definitions of Mitchum $\mathrm{Jr}$ et al. (1977) to determine the sequence boundaries, which are considered to be stratigraphic units of genetically related sequences with relatively concordant strata that are limited at their tops and bottoms by unconformities and their conformable equivalents.

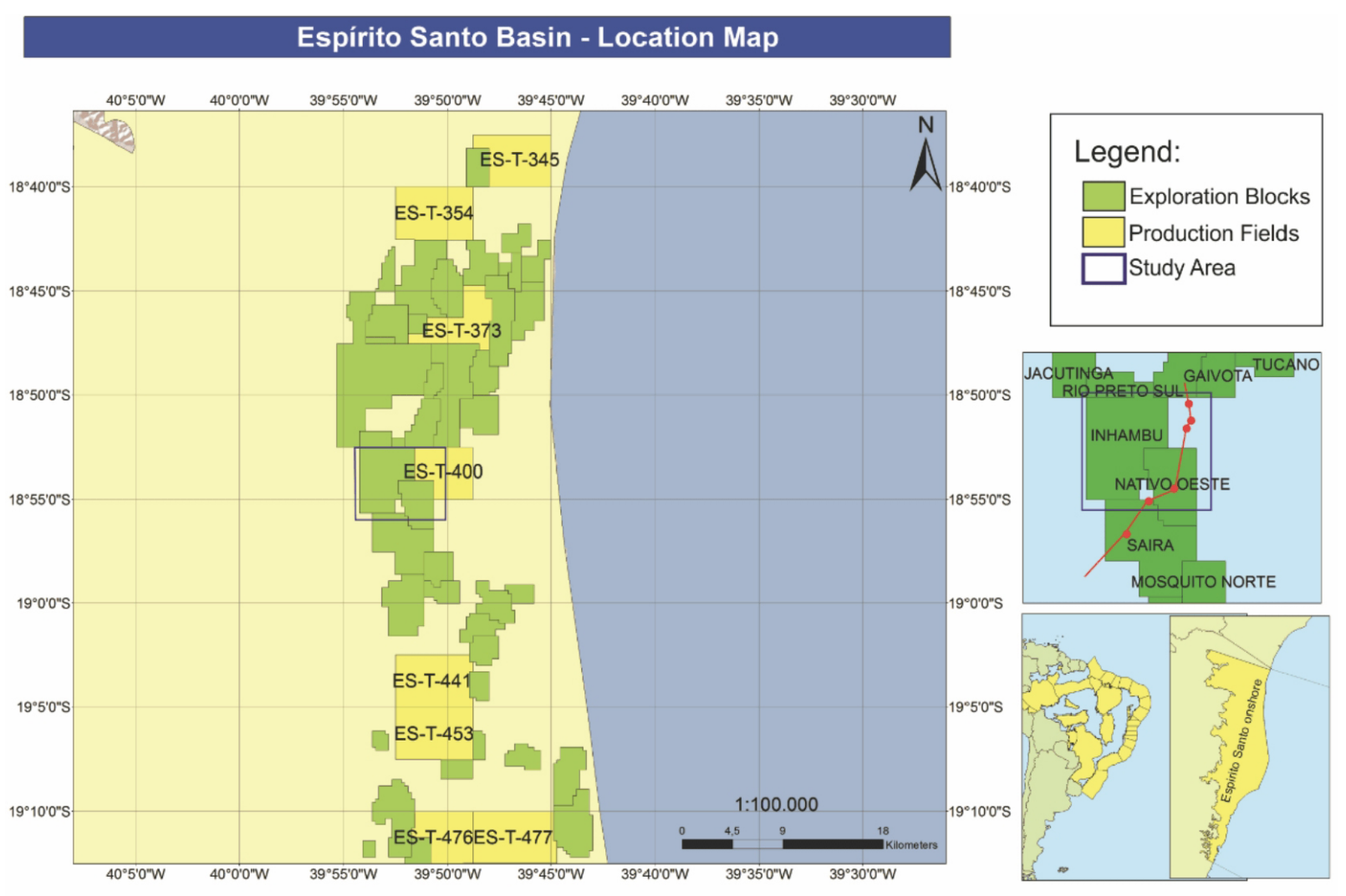

Figure 1 - Location map of the study area, onshore Espírito Santo Basin, Brazil. 


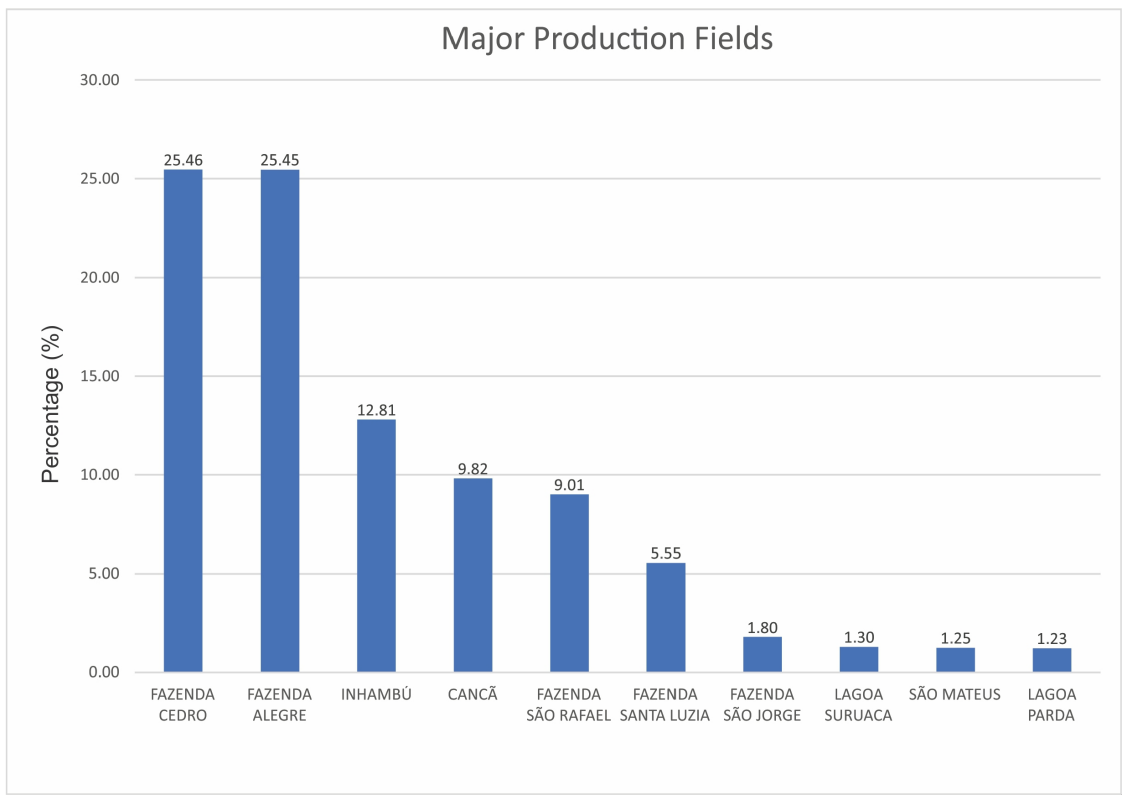

Figure 2 - Hydrocarbon production percentages of the main fields in the onshore Espírito Santo Basin in 2018 (BDEP, ANP).

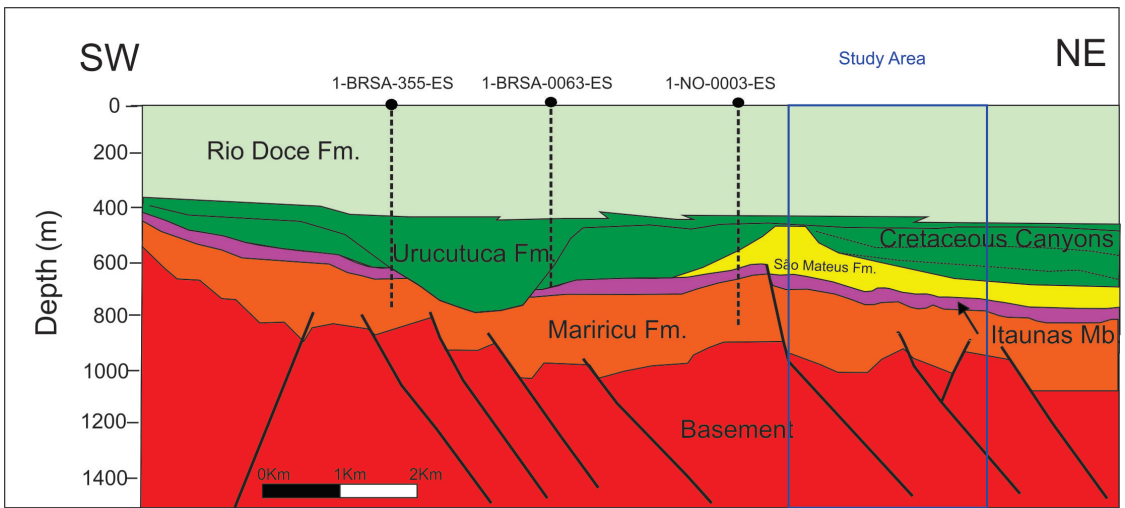

Figure 3 - Cross section showing the interpreted stratigraphy based on three industry wells and the literature (Neves et al., 2017). See Figure 1 for the location.

\section{HISTORICAL CONTEXT}

The Espírito Santo Basin is located on the eastern Brazilian margin and is limited to the south by the Vitória structural high, to the north by the Mucuri paleocanyon, to the west by crystalline basement and to the east by the Abrolhos volcanic complex (Carvalho, 1965). It covers an area of approximately 41,500 $\mathrm{km}^{2}$, of which $3,000 \mathrm{~km}^{2}$ is onshore. The basin stratigraphy was reviewed by França et al. (2007) and includes sedimentary rocks from the early Cretaceous to the Neogene that deposited over the Precambrian crystalline basement (Fig. 4).
The oldest sediments belonging to the Mariricu Formation and the Mucuri Member of the Cricaré Formation were deposited from the Valanginian to the lower Aptian during the rift phase of the basin, and they include lake deposits with fluvial and alluvial contributions near fault borders. The upper limit of the rift sequence is the pre-Alagoas regional unconformity at the top of the Mucuri Member (Dias, 2005). The Cabiúnas Formation represents a volcanic event during the E0-Cretaceous and is composed of basalts and diabases within the lacustrine sediments of the Mariricu Formation (Gomes \& Suita, 2012) (Fig. 4). 


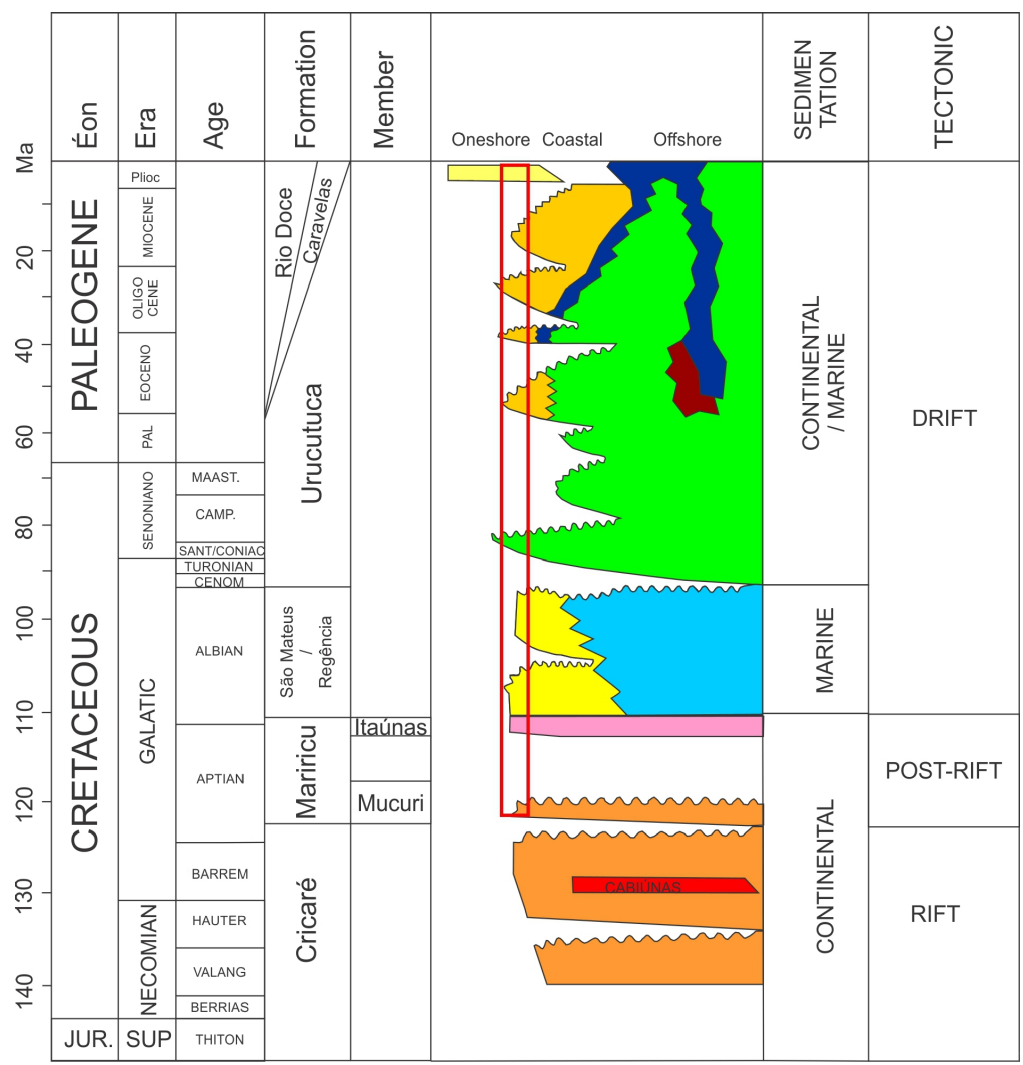

Figure 4 - Stratigraphic chart of the Espírito Santo Basin.

The post-rift interval consists of a single Aptian sequence (Cricaré Formation) that was deposited during quiescent tectonic conditions; it begins with sediments from fluvio-deltaic to sabka environments of the Mucuri Member and ends with evaporites (mostly halite and anhydrite) deposited in a restricted environment that correspond to the Itaúnas Member.

The drift sequence is represented by the Albian São Mateus Formation sandstones and by the Regência Formation carbonates, which were deposited in shallow marine environments. At the end of the Albian, a regional unconformity (pre-Urucutuca unconformity - PUU) eroded the Regência and Fazenda Cedro paleocanyons. A rapid subsidence and drowning of the Regência carbonate platform began in the Cenomanian and peaked during the Turonian with the deposition of the deep-water shales and turbidites of the basal Urucutuca Formation. In the onshore portion of the basin, the basal Urucutuca Formation shales are restricted to the intervening canyons. The Regência carbonates are partially preserved on two platforms, the São Mateus Platform and the Regência Platform, which were continuously covered by the Urucutuca shales (Fig. 3). The study area is located on the São Mateus Platform at the northern edge of the Fazenda Cedro Canyon (Fig. 5).

During the Paleogene, the Espírito Santo Basin experienced increased siliciclastic and carbonate sedimentation rates following the tectonic reactivation of the southeastern Brazilian margin. This reactivation resulted in the formation of the southeastern Brazil coastal ranges (Serra do Mar) and was followed by expressive volcanic events. The Abrolhos Volcanic Complex in the Espirito Santo Basin (Fig. 5) is the expression of this regional reactivation, which has been dated at 62 to 37 Ma (França et al., 2007). A mixed siliciclastic-carbonate shelf developed on the shallow margin starting in the Meso-Eocene, which is represented by the Rio Doce Formation (proximal shelf siliciclastics) and the Caravelas Formation (distal shelf carbonates).

The main source rocks in the onshore portion of the Espirito Santo Basin are the lacustrine shales of the upper rift sequence (Sernambi Member of the Cricaré Formation). Other potential source rocks are the black shale layers associated with the evaporites of the Mariricu Formation. Migration may have 

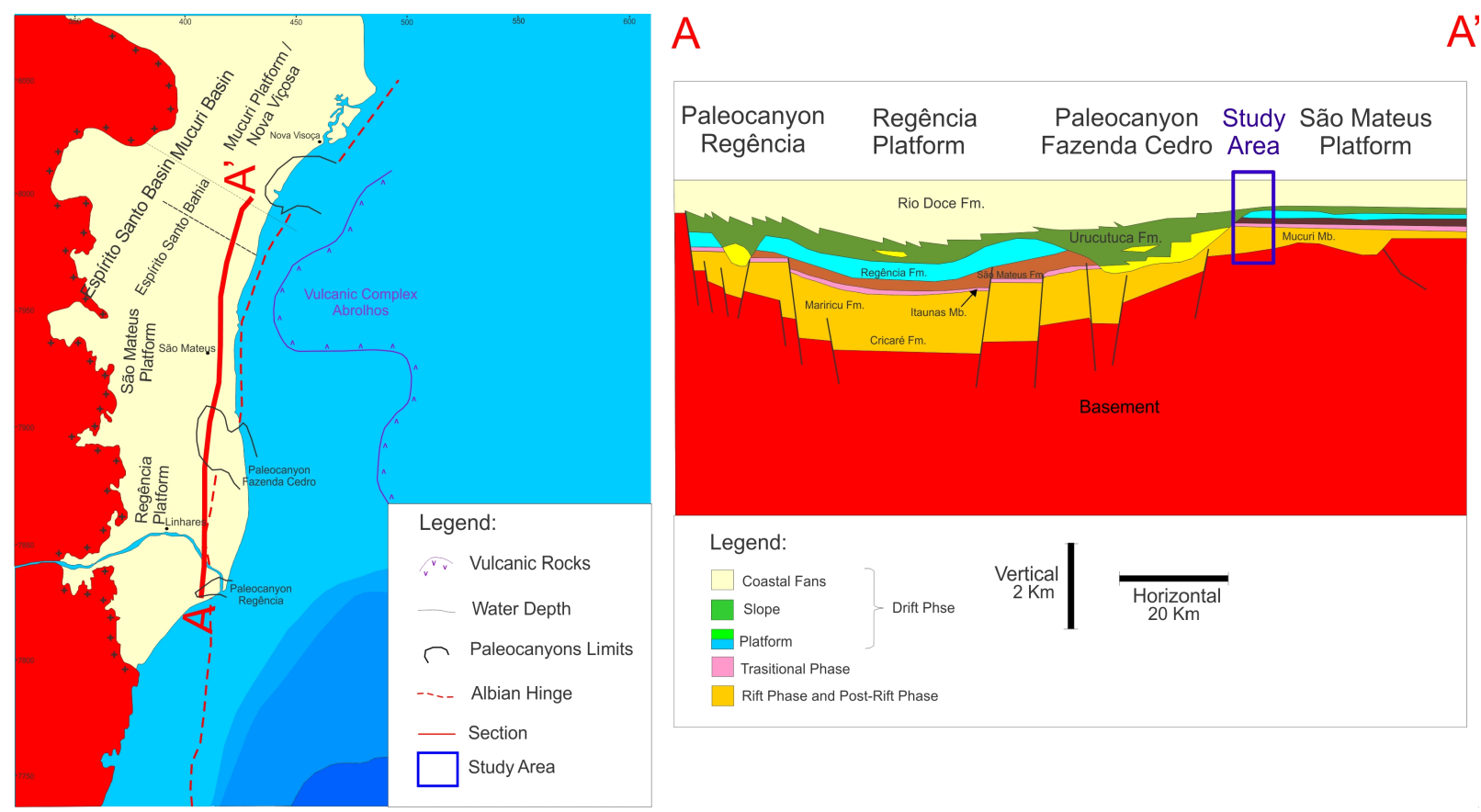

Figure $5-A)$ Location map of the study area; B) geological cross section showing the main rift structures, sedimentary units and morpho-sedimentary provinces.

occurred along fault planes in the rift section, along unconformity surfaces or by direct contact between the source rocks and the reservoirs. The reservoir rocks are located in the rift phase (Mucuri Formation), post-rift phase (Mariricu Member) and drift phase (Urucutuca Formation) sediments and are widely distributed throughout the basin.

(i)
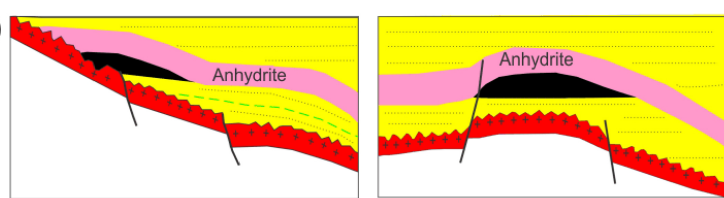

(ii)
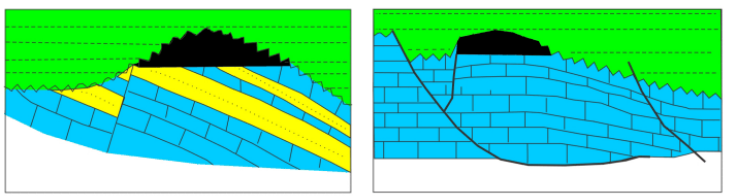

(iii)

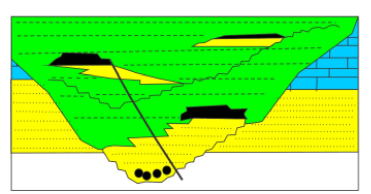

Figure 6 - Common hydrocarbon traps in the Espírito Santo Basin. (i) Structural traps within the rift section that are sealed by evaporites; (ii) combination structural and stratigraphic traps in carbonate reservoirs that are in erosional contact with shales; (iii) turbidite reservoirs that are erosionally truncated by canyons.
The traps identified on the onshore Espírito Santo Basin are diverse. Horsts, grabens and tilted blocks are common in the rift section and form structural traps on the São Mateus Platform. Structural, stratigraphic and combination traps are present in the drift section. Structural and combination traps related to rollovers and listric faults are located in the Regência Platform. Stratigraphic traps and reservoirs related to turbidites that are truncated against canyon walls are the main traps and reservoirs in the onshore basin (Fig. 6).

The evaporites of the Itaúnas Member (Mariricu Formation) are the seals of the oldest reservoirs. The shales of the Urucutuca Formation are the main seal in the basin, especially for the drift section reservoirs.

\section{METHODS}

This study is based on the interpretation of 3D seismic data, well logs and descriptions from three wells drilled in the vicinity of the Inhambú Field. The seismic reflection survey covers an area of approximately $50 \mathrm{~km}^{2}$, has a maximum penetration of 5 seconds two-way travel time (TWTT), and covers all of the Inhambú and Nativo Oeste oil fields (Fig. 7). The inline and crossline spacings are $12.5 \mathrm{~m}$ and $50 \mathrm{~m}$, respectively; the inlines are oriented north-south, and the crosslines are oriented east-west. In both fields, the main Cretaceous reservoir rocks are 


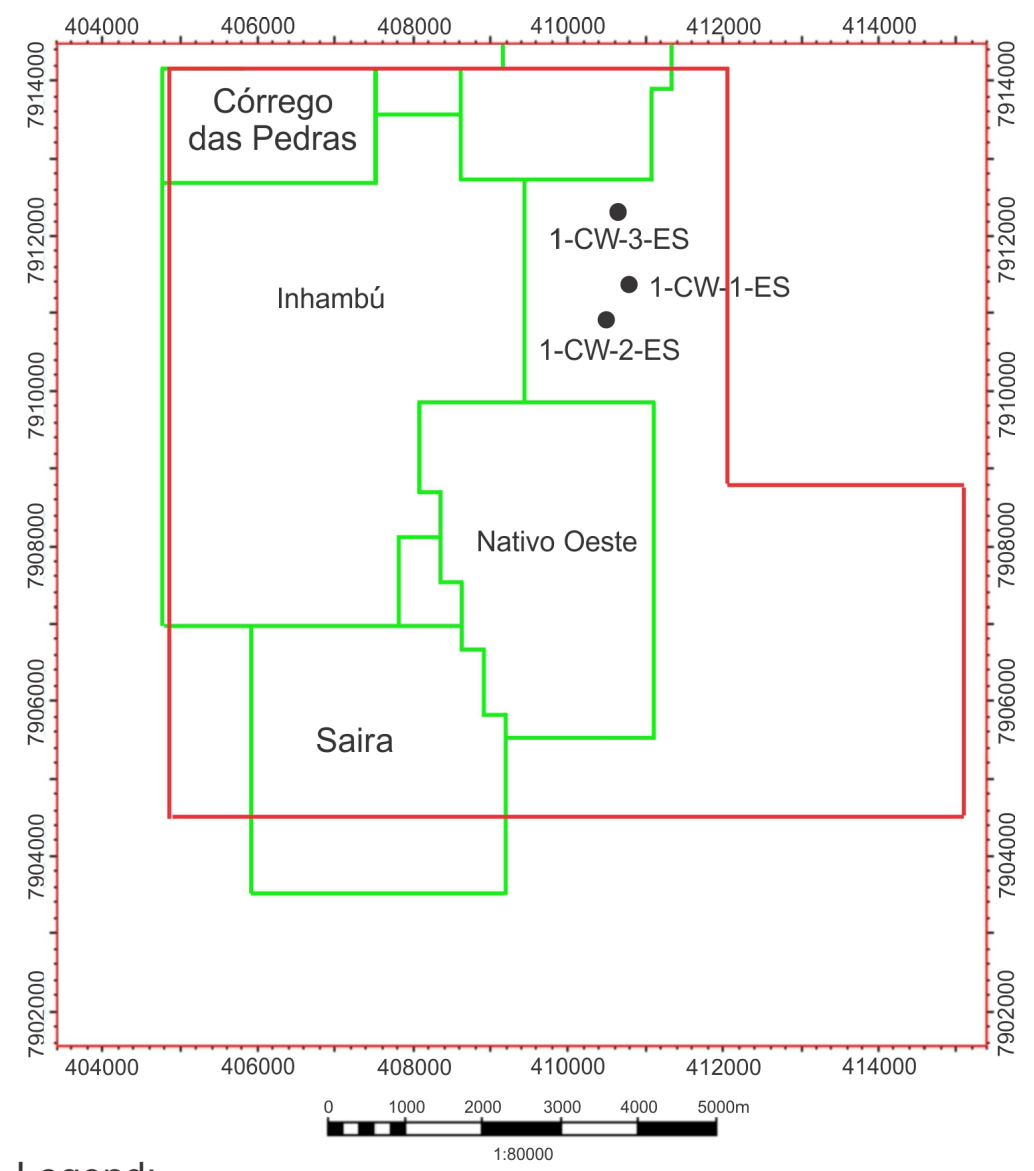

Legend:

Field

- Well

\section{Study area}

Figure 7 - Data used in this study. The seismic survey is represented by the red polygon, and the wells are represented by circles.

located in channels sealed by shales of the Urucutuca Formation. Wells 1-CW-1-ES, 1CW-2-ES and 1-CW-3-ES are located on the northeastern corner of the $3 \mathrm{D}$ block, approximately $1.1 \mathrm{~km}$ from the limits of the Inhambú Field. Wells 1-CW-1-ES and 1CW-2-ES reached the crystalline basement at depths of $1300 \mathrm{~m}$ and $1396.8 \mathrm{~m}$, respectively.

The interpretation of the seismic data initially consisted of the identification of the main depositional sequences related to the evolutionary stages established in the stratigraphic chart of França et al. (2007). The main horizons mapped correspond to the top of the basement; the intra-Mucuri unconformity; the post-rift unconformity (end of the post-rift phase); the base and top of the evaporites (Itaúnas Member); the pre-Urucutuca unconformity (Albian-Cenomanian); and the upper Eocene unconformity (base of the Rio Doce Formation). Structural maps were generated in TWTT for each of these horizons.

After detailed analyses of the lithologies and gamma-ray logs, the main $3^{\text {rd }}$-order depositional sequences were identified and tied to the seismic data. These sequences were separated by erosion and/or exposure surfaces, maximum flooding surfaces (MFS) and maximum regressive surfaces (MRS). The internal seismic facies were used regionally to aid in the seismic interpretation. This information was used to update the final geological model and to generate a chart of events indicating the 


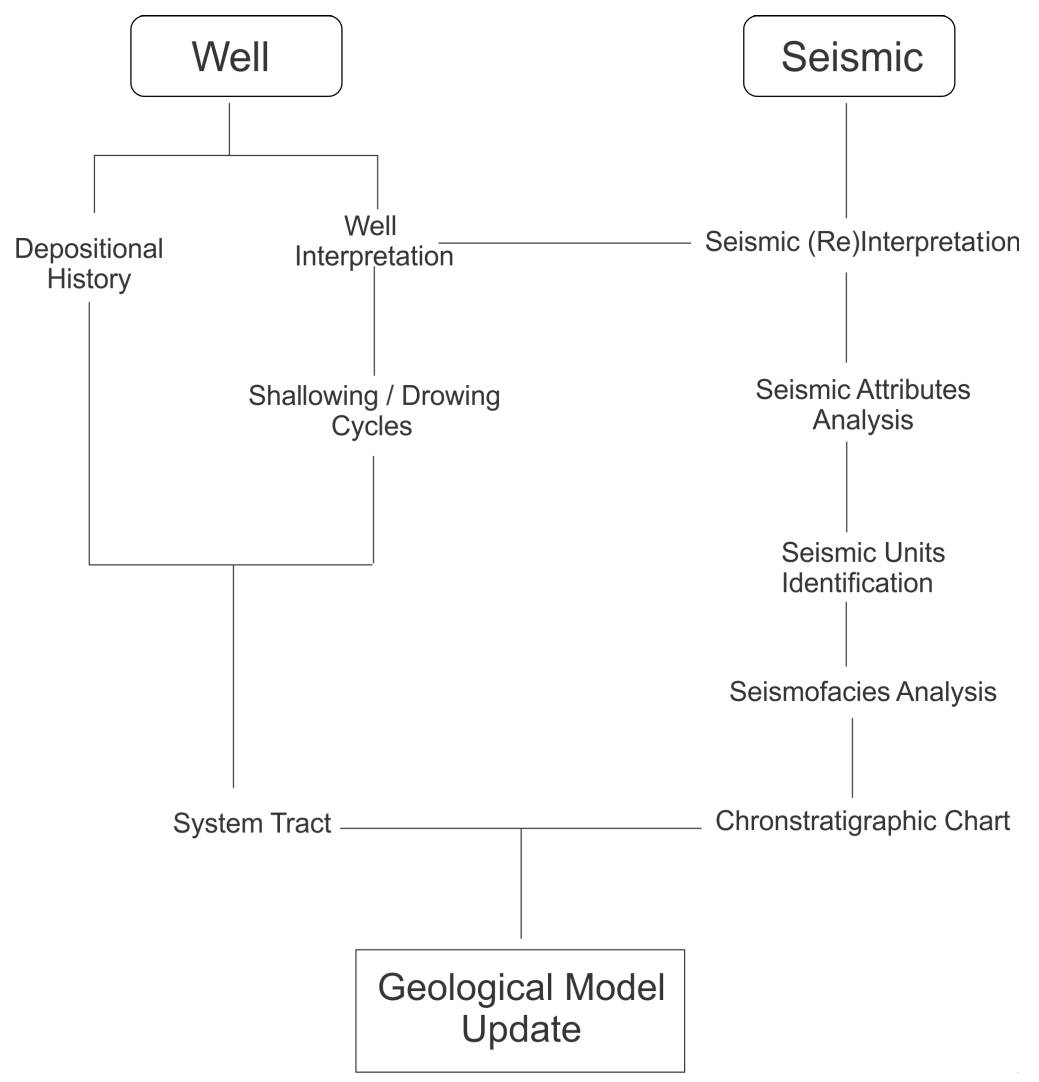

Figure 8 - Flow chart of the work.

critical times of the petroleum system elements and processes in the Inhambú oil field. Figure 8 shows a detailed flowchart of the work.

\section{RESULTS AND DISCUSSION}

The top of basement was encountered in wells 1-CW-1-ES and 1-CW-2-ES and is represented by undefined metamorphic rocks. Above the basement, the post-rift sandstones and shales of the Mariricu Formation are the deepest sedimentary units drilled. The Mucuri Member lithologies are 314 to $342 \mathrm{~m}$ thick. The top of the Mariricu Formation is well defined in all three wells and is represented by the Itaúnas Member anhydrites, which are an average of $40 \mathrm{~m}$ thick. These evaporites are clearly recognized in the seismic reflection data due to their high acoustic impedance contrast. Above the salt, the São Mateus Formation is represented by thick sandstone layers that are covered by thin intervals of the Urucutuca Formation shales, which decrease in thickness from SW to NE; this makes them difficult to identify in wells and seismic data (Fig. 9).
Figure 10 shows a seismic section oriented in the dip direction (W to $\mathrm{E}$ ). The interpreted seismic section illustrates the main horizons and depositional sequences identified in this study. The basement dips to the east from $600 \mathrm{~ms}$ to 1200 ms (two-way travel time) and is cut by normal faults that also affect the post-rift sequence. Most of the normal faults were active only in the initial post-rift phase and do not offset the intra-Mucuri unconformity, which was regionally mapped inside the post-rift sequence. A basement high, which is controlled by normal faults, is located near the center of the seismic section, and the seismic reflectors pinch out against this basement high. The pre-Urucutuca unconformity (PUU) is a prominent erosional surface that dissects two deep canyons with nearly $200 \mathrm{~ms}$ of local relief. From west to east, these canyons are the Inhambú and Fazenda Cedro canyons, which are separated by the basement high. The sedimentary infilling of the canyons was followed by another erosional phase that is represented by the upper Eocene unconformity (UEU) (Fig. 10).

These horizons and erosional unconformities bound six seismic-stratigraphic units: I) the initial post-rift unit from 
a)

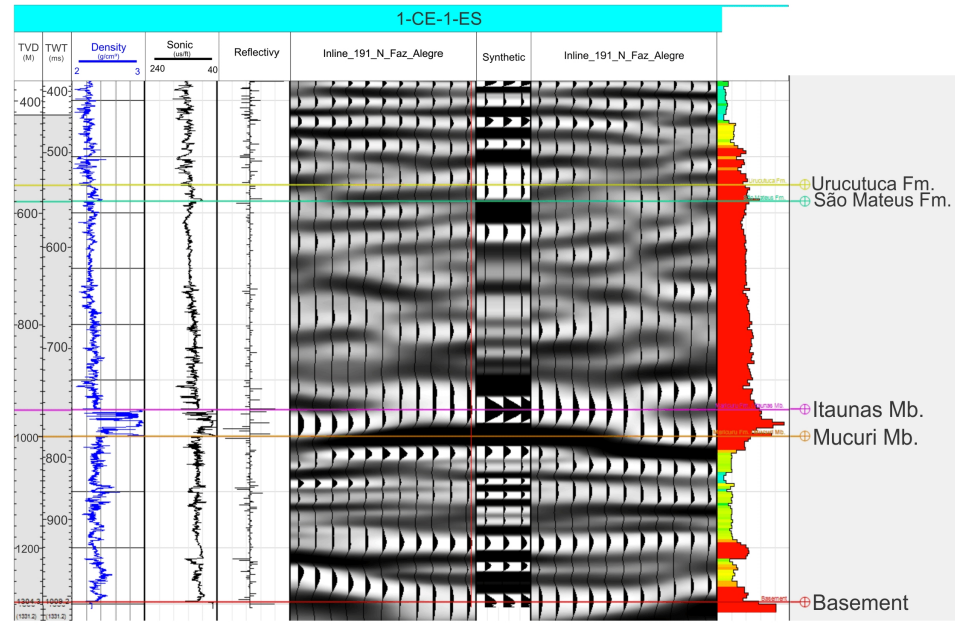

b)
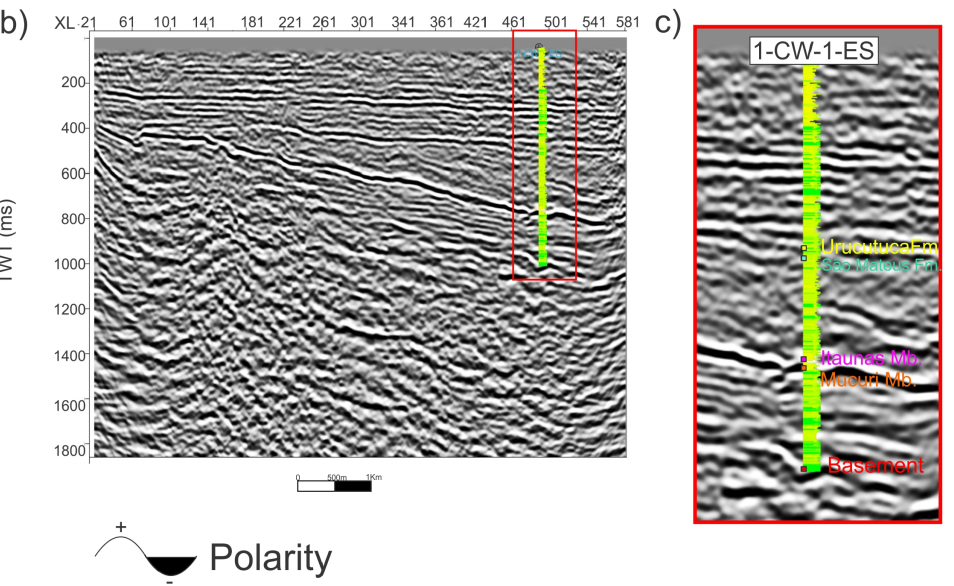

Figure 9 - A) Synthetic seismogram of well 1-CW-1-ES and well tops; B) inline 191 in time and well 1-CW-1-ES; C) expanded area of the well showing the well ties and seismic with well picks.

the basement to the intra-Mucuri unconformity, II) the lower transitional unit from the intra-Mucuri unconformity to the top of the post-rift sediments (base of the Itaúnas Member), III) the upper transitional unit, which corresponds to the Itaúnas Member evaporites, IV) the lower drift unit, which extends from the top of the Itaúnas Member to the pre-Urucutuca unconformity, V) the intermediate drift unit between the pre-Urucutuca and the upper pre-Eocene unconformities, and VI) the unit above the upper pre-Eocene unconformity (Fig. 10). These units generally correspond to depositional sequences related to the evolutionary stages established in the stratigraphic chart of França et al. (2007).

The interpretation of the well logs allowed the identification of $3^{\text {rd }}$-order cycles and system tracts (Fig. 11). Four regressive and two transgressive $3^{\text {rd }}$-order cycles were identified above the basement. The first regressive to transgressive system tract is located in the Mariricu Formation and is limited by a maximum flooding surface inside the Mucuri Member (Fig. 11). The Itaúnas Member anhydrites are a distinct stratigraphic marker in wells 1-CW-1-ES, 1CW-2-ES and 1-CW-3-ES, which records deposition during the transitional phase in a quiescent tectonic environment. During the deposition of the Itaúnas Member, an arid climate and excessive evaporation caused the deposition of the anhydrites in a very shallow lake, which characterizes a second regressive system tract ending at a maximum regressive surface (MRS) on top of the Itaúnas Member (Fig. 11). This surface corresponds to the climax of arid conditions. The third regressive to transgressive third-order cycle includes all of the São Mateus and Urucutuca formations and most of the Rio Doce Formation.

The structural maps in Figure 12 show the two-way travel times (TWTTS) to the main horizons and unconformities. The 


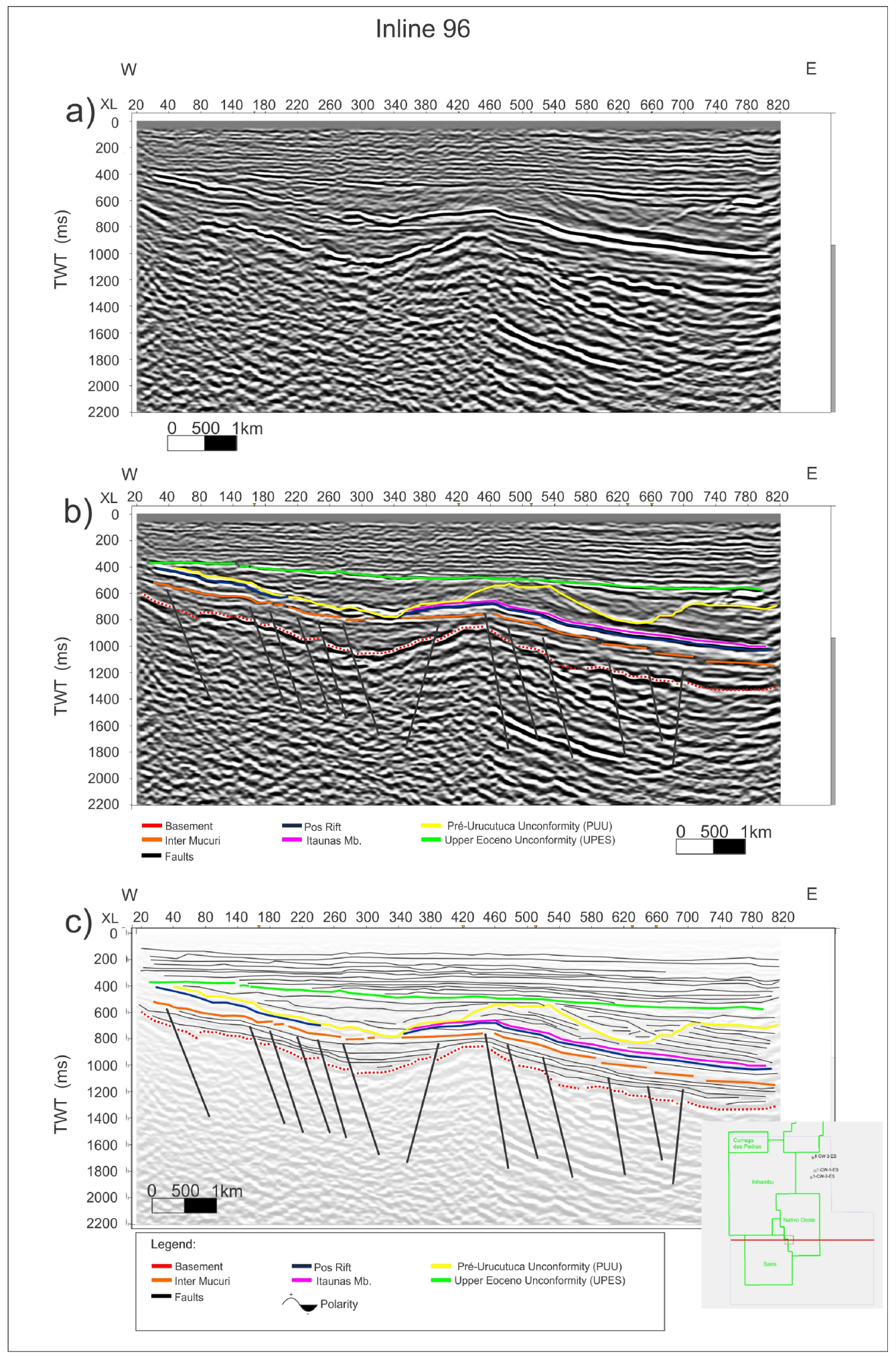

Figure 10 - A) Seismic inline (96) oriented in the dip direction (E-W); B) interpreted seismic section; C) interpretation of seismic units. 


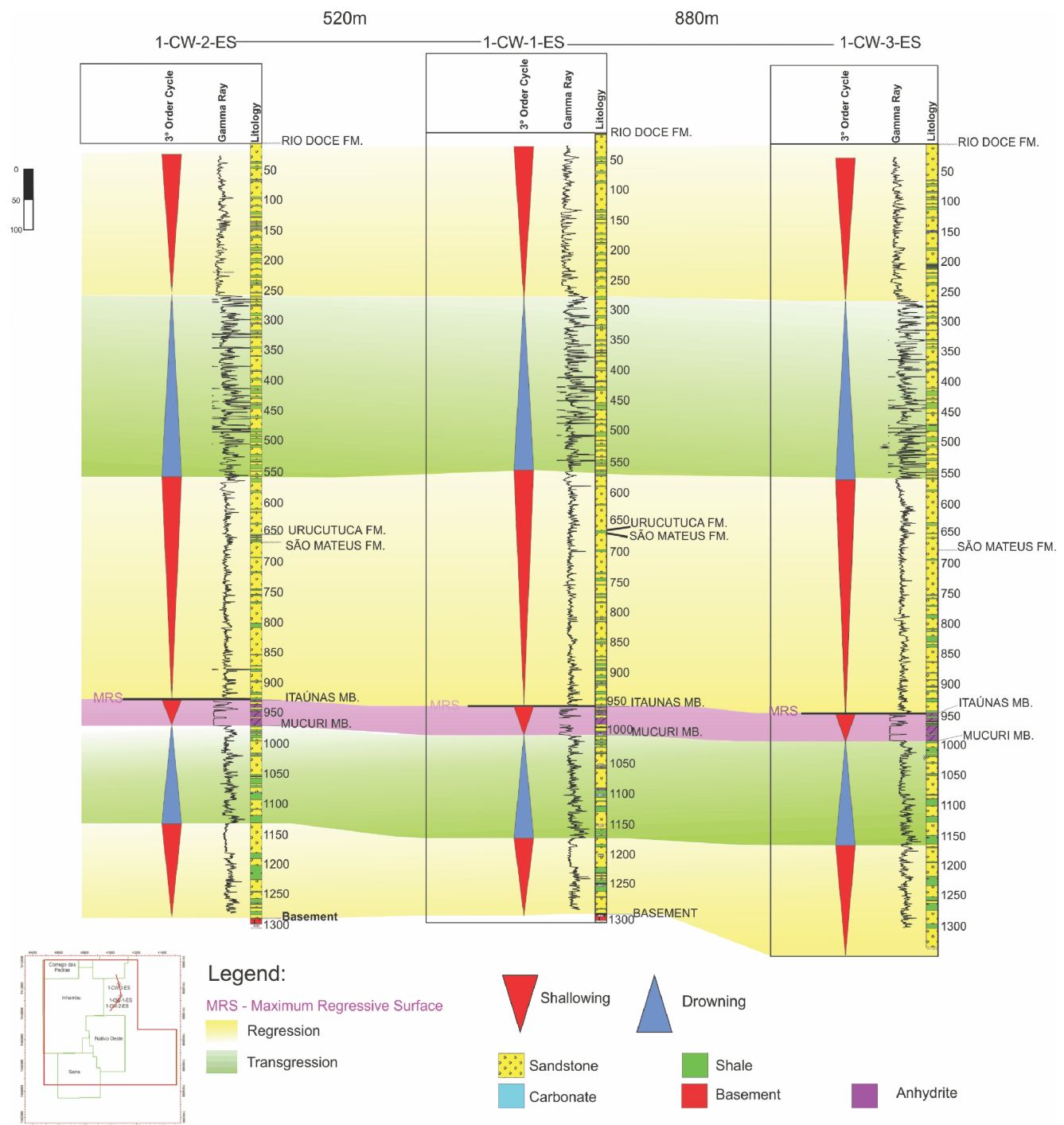

Figure 11 - Third-order cycles showing the system tracts based on the shallowing/drowning cycles in wells 1-CW-1-ES, 1-CW-2-ES, 1-CW-3-ES, onshore Espírito Santo Basin.

upper Eocene unconformity (UEU) structural map reveals a homoclinal slope dipping gently to the southeast (Fig. 12a). The pre-Urucutuca unconformity (PUU) isochron grid reveals the Inhambú (Fig. 12b) and Fazenda Cedro (Fig. 12c) canyons with well-defined N-S-oriented thalwegs. The isochron maps to the top of the Itaúnas Member and to the post-rift unconformity are slightly different (Figs. 12d and 12e). The Itaúnas Member was eroded away by PUU in the Inhambú Canyon area, but it is still present under Fazenda Cedro Canyon (Fig. 12d). The top of the intra-Mucuri unconformity was also partially eroded by Fazenda Cedro Canyon (Fig. 12f) and has a NE-SW hinge at greater depths (from -900 to $-1100 \mathrm{~ms}$ ). The isochron map to the top of the basement reveals the same NE-SW structural hinge at greater depths (Fig. 12g), which is controlled by the basement high shown in the seismic sections (Figs. 10 and 13). Only small normal faults displace the intra-Mariricu unconformity (Fig. 13), which indicates a relative quiescent tectonic environment that is analogous to the SAG phase of the Campos and Santos basins, which culminated with the deposition of evaporites (Itaúnas Member).

We identified four seismic facies with different seismic patterns (Fig. 14). These seismic facies were recognized within the mapped stratigraphic sequences, including the basement (Precambrian), intra-Mucuri, top of the post-rift sequence, 
a)

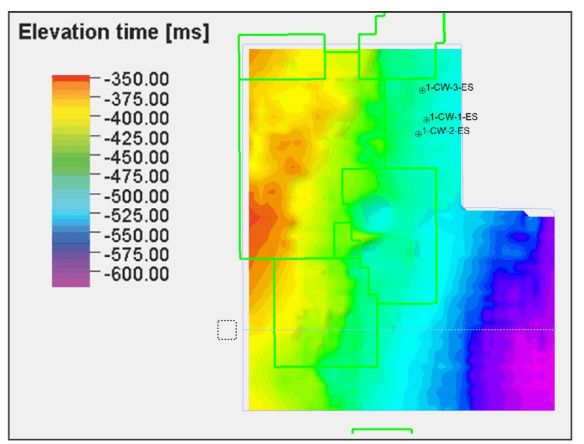

b)

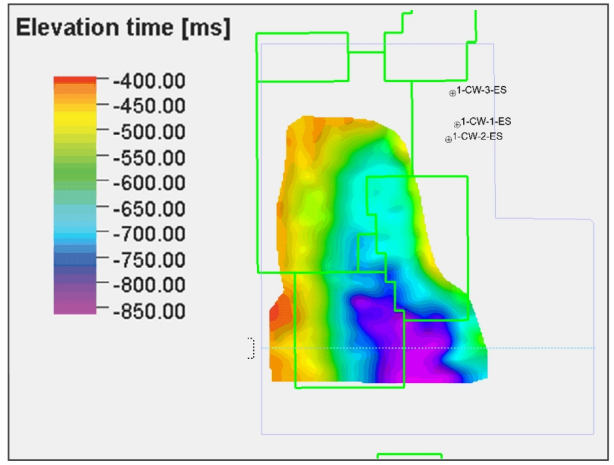

d)

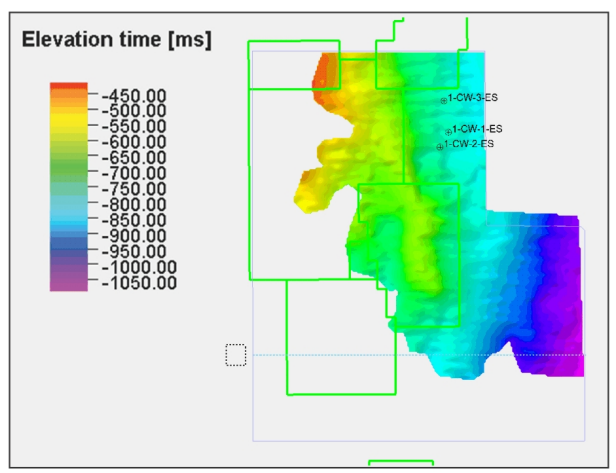

f)

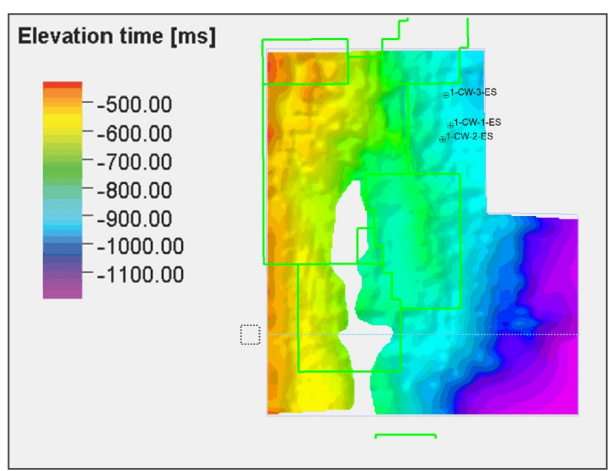

c)

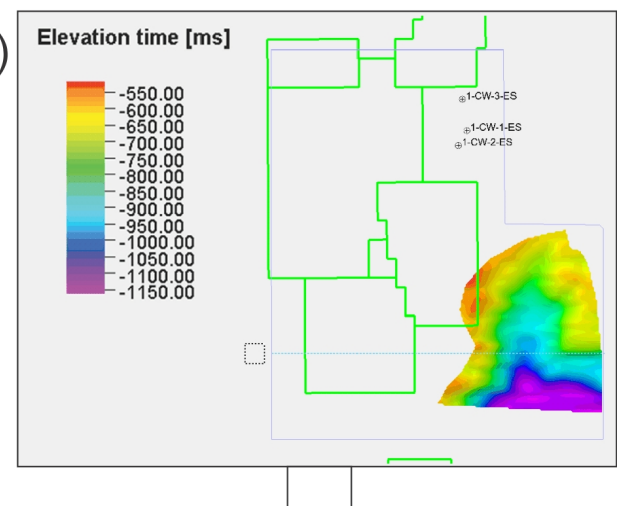

e)

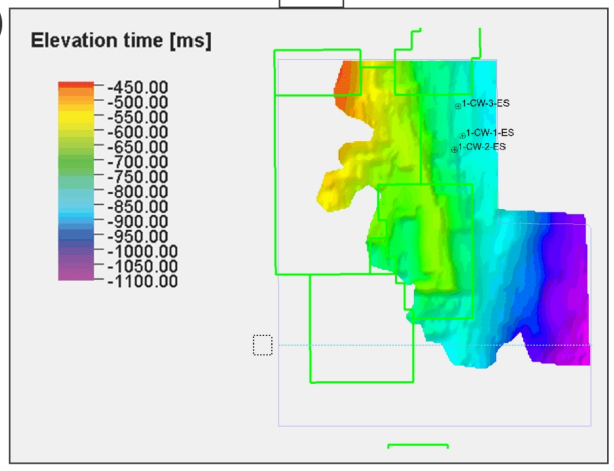

g)

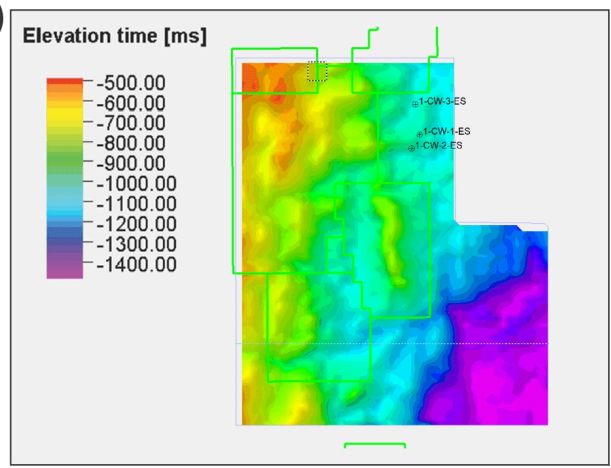

Figure 12 - Structural isochron maps (TWTT) of the main interpreted horizons and unconformities. a) Upper pre-Eocene unconformity; b) pre-Urucutuca unconformity in the Inhambú Canyon area; c) pre-Urucutuca unconformity in Fazenda Cedro Canyon; d) top of the Itaúnas Member evaporites.; e) post-rift unconformity; f) intra-Mucuri unconformity; g) basement. 


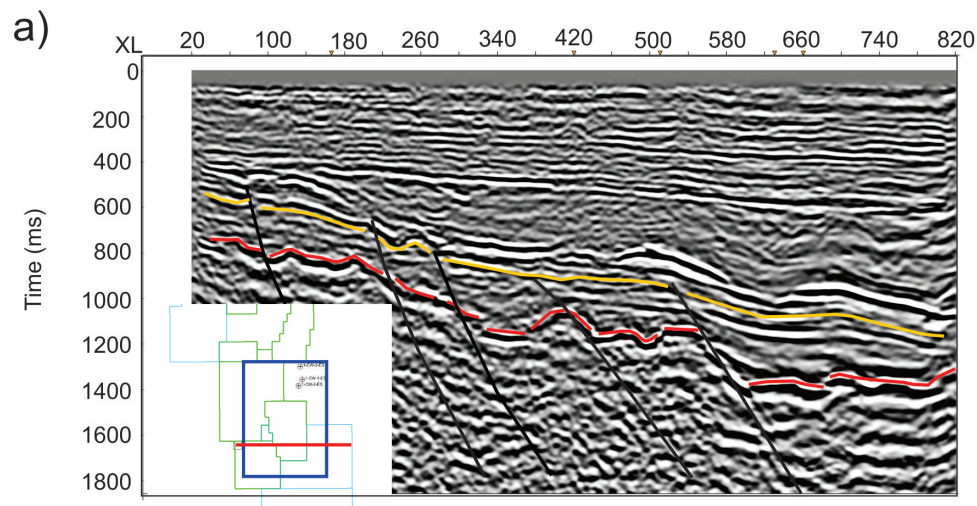

b)

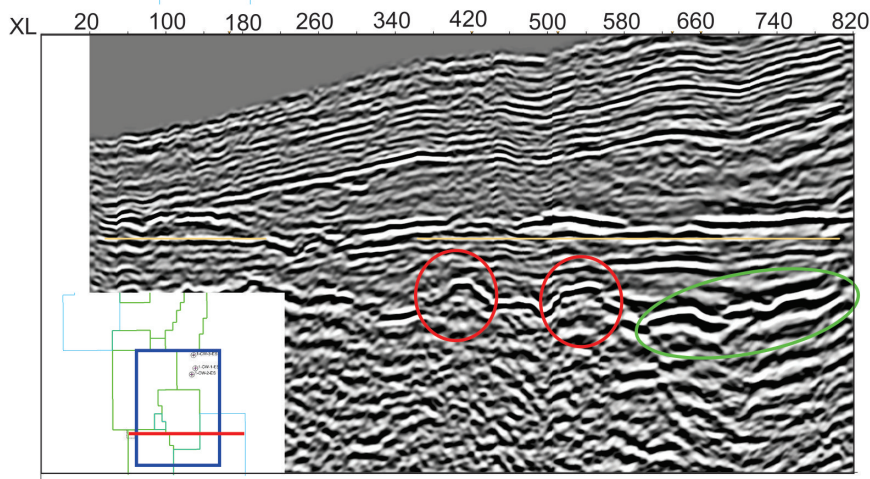

Figure 13 - a) Unflattened seismic data; b) seismic data flattened on the intra-Mucuri horizon (depositional lows are highlighted in green, and the structural paleo-highs highlighted in red).

base of salt (anhydrite), pre-Urucutuca and upper pre-Eocene unconformity.

The basement is characterized by chaotic reflections (seismic facies "A"). Seismic facies "B" is located within the post-rift sequence and contains divergent and hummocky reflectors that are semi-continuous with low to medium amplitudes. We interpreted this section to be the result of fan delta progradation.

The upper sequence of the Mariricu Member and the Itaúnas Member anhydrites are characterized by seismic facies " $\mathrm{C}$ ", which contains high amplitude, low frequency reflectors with subparallel to parallel configurations and a wedge-shaped geometry. This seismic facies was deposited non-conformably on the underlying strata.

Seismic facies "D" is characterized by sub-parallel, divergent, oblique to tangential and hummocky reflectors with medium to high frequencies and low to high amplitudes. This unit was truncated by the pre-Urucutuca unconformity during the excavation of the early Cretaceous canyons (Fig. 14).

The infilling of the canyons above the pre-Urucutuca unconformity is again represented by seismic facies "B", which contains onlapping and subparallel low to medium amplitude reflectors (Fig. 14).

The uppermost seismic units are characterized by parallel to sub-parallel, continuous, high-frequency reflectors with medium to high amplitudes (seismic facies "C").

The chronostratigraphic chart of events (Fig. 15) includes 37 relative time events that explain the depositional history of the basin and the tectonic and sedimentary factors that controlled sedimentation. The faults that deform the post-rift section were interpreted as reactivated rift faults because no growth section was observed. The basal section is represented by the Mariricu Formation (Mucuri Member), which was deposited during the Lower and Middle Aptian and reached its maximum extent during relative time $\mathrm{T} 6$.

Above the intra-Mucuri unconformity, the absence of faults and the tabular nature of the reflectors with few variations of seismic thickness indicate a calm tectonic environment. A marine transgression was followed by a regression, which culminated with the precipitation of anhydrites in an evaporitic environment (lower Aptian). 


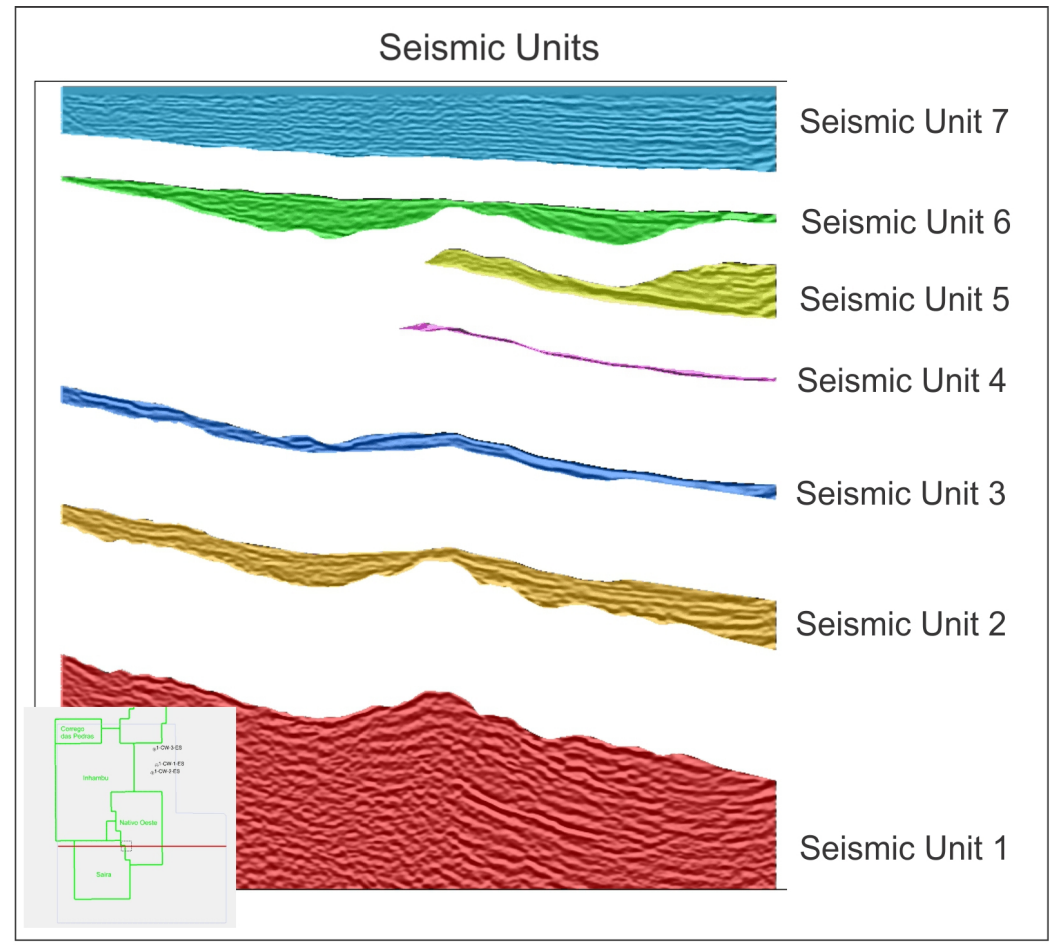

\begin{tabular}{|c|c|c|c|c|}
\hline $\begin{array}{c}\text { Seismic } \\
\text { Units }\end{array}$ & $\begin{array}{l}\text { Seismic } \\
\text { Facies }\end{array}$ & Description & Example & Interpretation \\
\hline 1 & A & $\begin{array}{l}\text { Chaotic configuration } \\
\text { and Low Reflectivity, } \\
\text { descontinous reflectors }\end{array}$ & & $\begin{array}{l}\text { Based on wells, this reflections } \\
\text { are associated with } \\
\text { Metamorfic non Identify Rocks }\end{array}$ \\
\hline 2 & B & $\begin{array}{l}\text { Subparallel to divergent, } \\
\text { and hummocky } \\
\text { reflection configuration, } \\
\text { onlap termination, } \\
\text { semi-continous } \\
\text { to low reflection }\end{array}$ & & $\begin{array}{l}\text { Associated with the } \\
\text { inter-deltaic area } \\
\text { of shallow water }\end{array}$ \\
\hline 3 & C & $\begin{array}{l}\text { Parallel to subparallel, } \\
\text { semi-continous good } \\
\text { reflections, low frequency }\end{array}$ & & $\begin{array}{l}\text { Basin-Drowing event, } \\
\text { Sabkha (?) }\end{array}$ \\
\hline 4 & $\mathrm{D}$ & $\begin{array}{l}\text { High Amplitude and } \\
\text { Continuity }\end{array}$ & & $\begin{array}{l}\text { Based on wells, } \\
\text { this reflections } \\
\text { are assotiated } \\
\text { with anhydrite, drowing and } \\
\text { aridy environment }\end{array}$ \\
\hline 5 & $E$ & $\begin{array}{l}\text { Parallel and sub-parallel, } \\
\text { with medium and high } \\
\text { amplitude, } \\
\text { erosive trucation }\end{array}$ & & $\begin{array}{l}\text { Initial stage of drift phase, } \\
\text { composed predominantly by } \\
\text { shallow plataform sandstone } \\
\text { of São Mateus Formation }\end{array}$ \\
\hline 6 & $\mathrm{~F}$ & $\begin{array}{l}\text { Mouded onlap to } \\
\text { complex, low continuity } \\
\text { and amplitude and } \\
\text { geometry is filling channel }\end{array}$ & & $\begin{array}{l}\text { Filling channel, by the } \\
\text { Urucutuca Formation shale }\end{array}$ \\
\hline 7 & G & $\begin{array}{l}\text { Parallel configuration } \\
\text { reflectors, with good } \\
\text { continuity and amplitude, } \\
\text { high frequency } \\
\text { and sheet geometry }\end{array}$ & & $\begin{array}{l}\text { Subaqueous enviromenty, } \\
\text { quiescence tectonic, with } \\
\text { layer geometry }\end{array}$ \\
\hline
\end{tabular}

Figure 14 - Correlations between seismic units, seismic facies, descriptions and interpretations. 


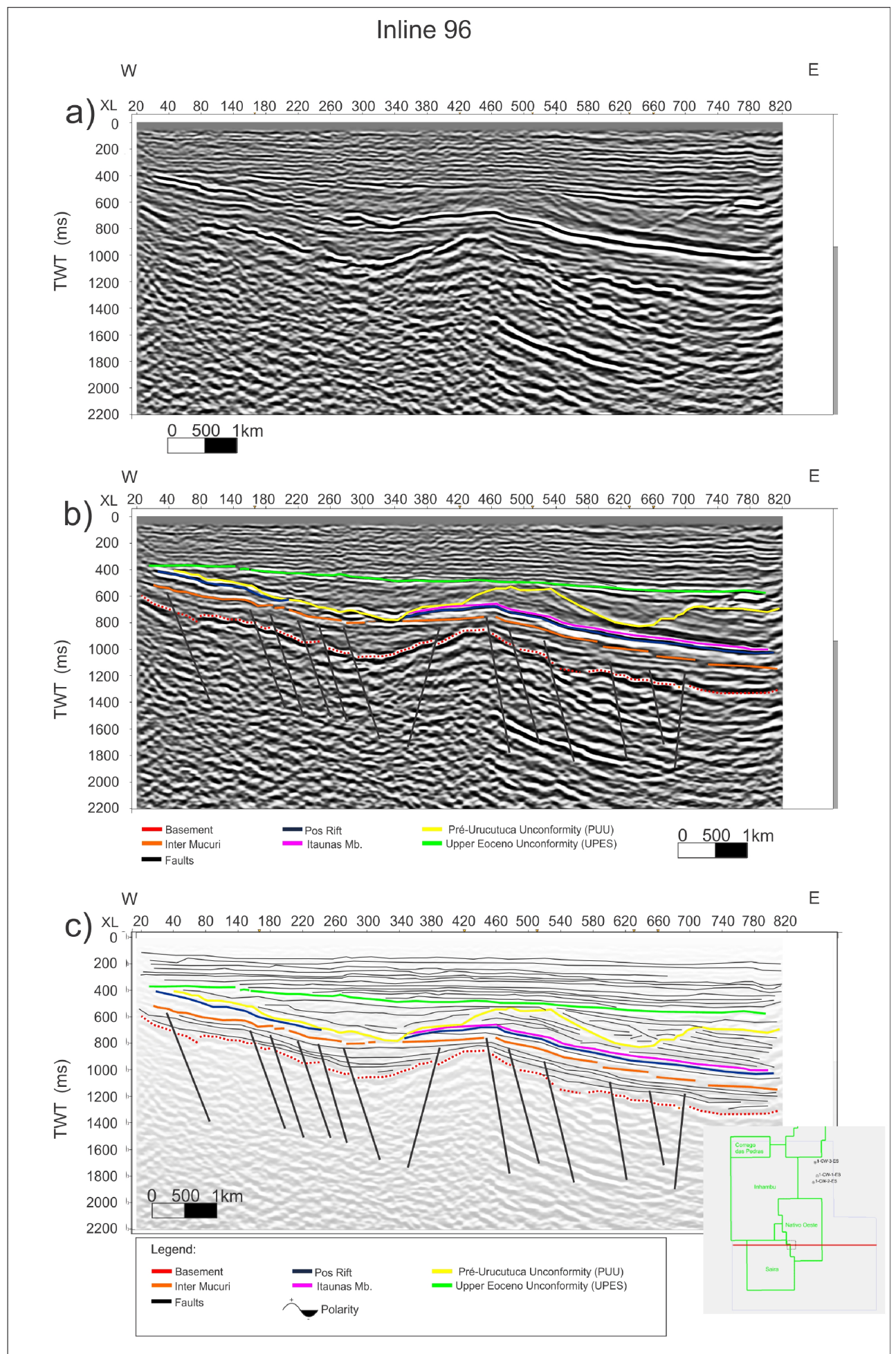

Figure 15 - a) Seismic stratigraphic units; b) system tracts interpreted based on the seismic stratigraphic units; c) chart of chronostratigraphic events indicating the main transgressive and regressive events during the deposition of the sequences. 


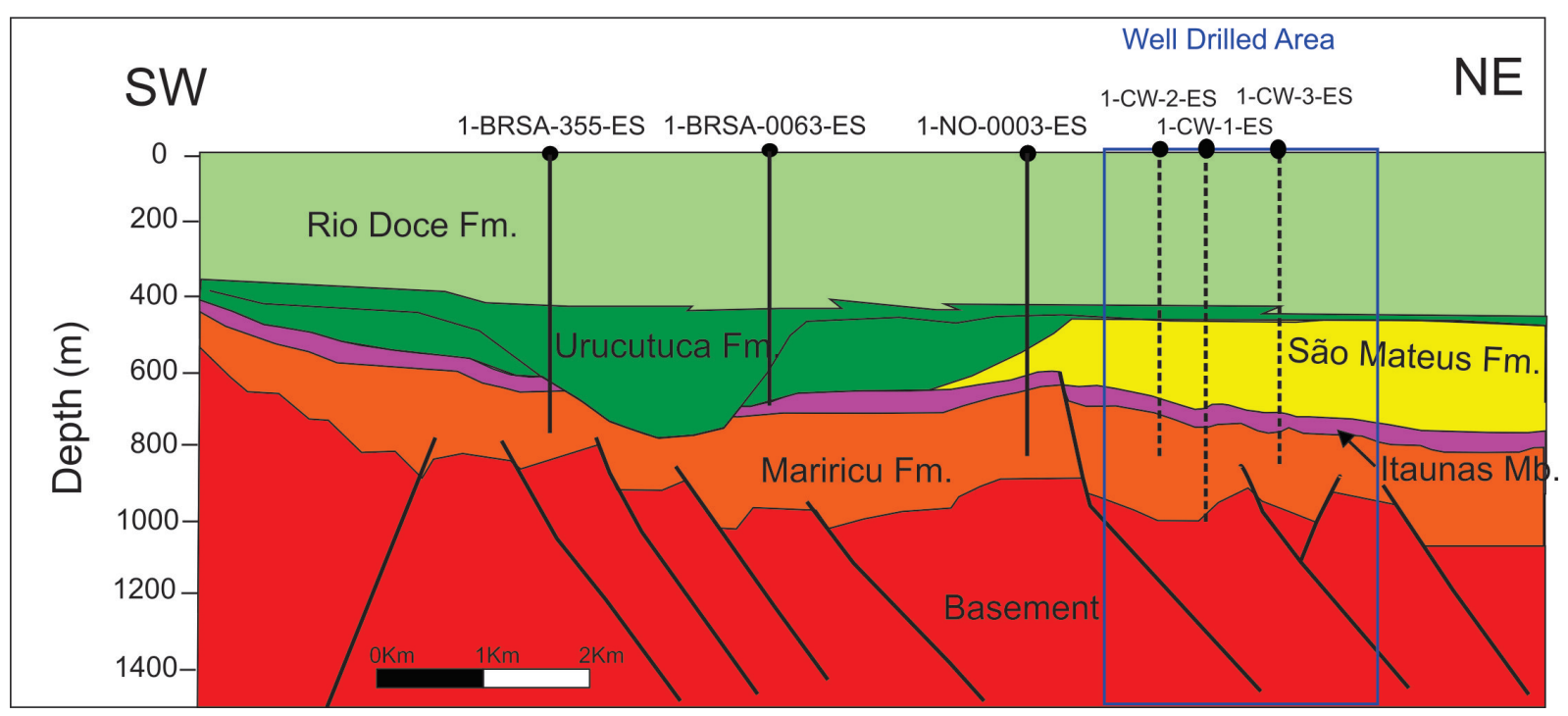

Figure 16 - New geological model based on the well and seismostratigraphic studies.

After the evaporitic phase, the São Mateus Platform contains a predominance of sandstones and shales of the São Mateus Formation. These onlap onto the surface of the Itaúnas Member, are thicker to the north, and were completely eroded away to the west by the Inhambú and Fazenda Cedro paleocanyons. The pre-Urucutuca unconformity marks the bases of the canyons that were filled during the basin's thermal subsidence by shales of the Urucutuca Formation. We interpreted a maximum flooding surface at the top of this section (relative time T27 in Fig. 15c).

The upper pre-Eocene unconformity can be associated with tectonic uplift during the Serra do Mar uplift and Abrolhos volcanism, which controlled the distribution of sands from the northwest during the Lower Oligocene. The Rio Doce Formation was deposited in a predominantly regressive tract starting in the upper Eocene.

Based on the information from wells 1-CW-1-ES, 1CW-2-ES and 1CW-3-ES and the seismic interpretation, a new geological model is proposed, which shows that the Cretaceous canyons did not exist in the northern part of the study area (Fig. 16). This model is different from the previous model (Fig. 3) and significantly changes the interpretation of the basin's stratigraphy in the study area. This model will have a significant impact on exploration when considering the importance of the Urucutuca and São Mateus formations sandstone reservoirs in the Espírito Santo Basin. The main reservoirs on the São Mateus Platform are not the Urucutuca Formation sandstones. In addition, the Mariricu Formation fluvial sandstones may be considered the main reservoirs in the northeastern portion of the Espírito Santo Basin.

\section{CONCLUSIONS}

We developed a regional tectonic-stratigraphic framework in the eastern part of the Inhambú Field, Espírito Santo Basin. The structural contour and isochron maps, which are both in time (TWTT), show significant changes in the basal and intermediate parts of the post-rift section (Mariricu Member) without syntectonic deformation. The Inhambú and Fazenda Cedro canyons did not erode the eastern part of the basin, where the São Mateus sandstones and shales are still preserved. The seismic interpretation allowed the definition of 34 seismic events that are summarized in a chronostratigraphic chart of events. A new geological model is proposed, which reduces exploratory uncertainties for the drilling of new wells. Previous models identified the sandstones of the Urucutuca Formation as the main reservoir rocks and petroleum accumulations in stratigraphic traps, such as the Fazenda Cedro and Fazenda Alegre fields. This study demonstrates that the main reservoir unit on the São Mateus Platform is the Mucuri Member, which consists of neo-Aptian fluvial-deltaic sandstones that were deposited during the marine transgression and subsequent regression that culminated with the deposition of the Itaúnas Member anhydrites. 


\section{ACKNOWLEDGEMENTS}

The authors thank the Agência Nacional do Petróleo, Gás Natural e Biocombustíveis (ANP) for providing the seismic data used in this study and Schlumberger for providing the Petrel software license. The first author thanks the Conselho Nacional de Desenvolvimento Científico e Tecnológico (CNPq) and the Coordenação de Aperfeiçoamento de Pessoal de Nível Superior (CAPES) for financial support.

\section{REFERENCES}

CARVALHO KWB. 1965. Geologia da bacia sedimentar do rio Almada. Boletim Técnico da Petrobras, 8(1): 5-55.

DIAS JL. 2005. Tectônica, estratigrafia e sedimentação no Andar Aptiano da margem leste brasileira. Boletim de Geociências da Petrobras, 13(1): $7-25$.

Recebido em 19 junho, 2018 / Aceito em 12 agosto, 2018

Received on June 19, 2018 / accepted on August 12, 2018
FRANÇA RL, DEL REY AC, TAGLIARI CV, BRANDÃO JR \& FONTANELLI PR. 2007. Bacia do Espírito Santo. Boletim de Geociências da Petrobras, 15(2): 501-509.

GOMES NS \& SUITA MTDF. 2012. Ocorrência de vulcanismo bimodal de idade terciária na Bacia de Mucuri. B. Geoci. Petrobras, 18(2): 233-248.

MITCHUM JR RM, VAIL PR \& SANGREE JB. 1977. Seismic stratigraphy and global changes of sea level: Part 6. Stratigraphic interpretation of seismic reflection patterns in depositional sequences: Section 2. Application of seismic reflection configuration to stratigraphic interpretation. AAPG Special Volumes A165, 117-133.

NEVES IA, LUPINACCI WM \& SILVA CG. 2017. Seismostratigraphic analysis in the Inhambu Field, Espirito Santo Basin, Brazil. In: 15th International Congress of the Brazilian Geophysical Society \& EXPOGEF, Rio de Janeiro, Brazil, 31 July-3 August 2017, p. 463-466. Brazilian Geophysical Society. 